\title{
Measurement of Permeability of Magnetic Thin Film by Meander-Type Probe
}

\author{
J. Takahashi, A. Sato*, S. Yabukami*, T. Ozawa, Y. Miyazawa**, K. Yanagi**, and Y. Shimada*** \\ Sendai National College of Technology, 48 Nodayama, Medeshima-Shiote, Natori, Miyagi 981-1239, Japan \\ *Department of Electrical Engineering and Information Technology, Tohoku Gakuin University, 1-13-1 Chuo, Tagajo 985-8537, \\ Japan \\ **Toei Scientific Industrial co., Ltd., 75 Kitaoki, Iino-aza, Natori, Miyagi 981-1225, Japan \\ ${ }^{* * *}$ Graduate School of Engineering, Tohoku University, 6-6, Aramaki Aza Aoba, Aoba-ku, Sendai, Miyagi 980-8579, Japan
}

\begin{abstract}
A highly sensitive method of obtaining the permeability of magnetic film without limitations in sample size was developed based on the electrical impedance of magnetic film in contact with microstrip meander lines. The permeability of a CoNbZr thin film $(25 \times 25 \mathrm{~mm}, 0.1-\mu \mathrm{m}$ thick $)$ was evaluated in a frequency range of $100 \mathrm{MHz}-8$ $\mathrm{GHz}$; the measured values roughly corresponded to those obtained with the Landau-Lifshitz-Gilbert equation. The proposed method shows promise for measuring the permeability of wafer-sized samples because it is not restricted by size limitations.
\end{abstract}

Keywords: permeability, magnetic thin film, meander line

\author{
ミアンダ形プローブによる磁性薄膜の透磁率計測 \\ 高橋純也・佐藤彰*・薮上信*・小澤哲也・宮澤安範**柳邦雄**島田寛 ${ }^{* * *}$ \\ 仙台高等専門学校, 名取市愛島塩手字野田山 48 ( ( $981-1239)$ \\ *東北学院大学工学部, 多賀城市中央 1-13-1 (广985-8537) \\ **東栄科学産業, 名取市飯野字北沖 75 ( $\bar{\top} 981-1225)$ \\ ***東北大学大学院工学研究科, 仙台市青葉区荒巻字青葉 6-6 (广980-8579)
}

\section{1. はじめに}

我々の身の回りにある携帯電話やパソコンなどの電子機 器は高周波化が進んでおり，携帯電話においては大量のデ 一夕送受信の必要性や通信方式・周波数の国際標準対応と いったグローバル化，小型化などの点から $\mathrm{GHz}$ 帯の周波数 が使用されるようになった。このように電子機器内部の高 周波化は，高周波用磁性材料の開発を加速させ，それに付 随した新しい評価方法の研究も盛んに行なわれている. 特 に高周波領域におけるインダクタンス特性や損失を決定す る高周波透磁率評価方法の確立は必須のものとなってい る.

従来の磁性薄膜の高周波透磁率評価方法には, 8 の字コイ ル法 ${ }^{1)}$, シールディッドループコイルを用いる方法 ${ }^{2)}$, 伝送 線路を用いる方法 3)等が挙げられる. しかし，これらの方 法は評価周波数の上限が検出コイルなどの共振周波数によ り制限されてしまうため評価できる試料の大きさに制限が ある。そのため， ウエ八や基板から透磁率評価用の小さな 試料を切り出して計測することが必要であり， ウエ八等の 透磁率をインラインで評価することは困難であった。

筆者らは，これまで磁性薄膜に直接高周波電流を通電さ せて, 厚さが $4 \mu \mathrm{m}$ の CoNbZr 薄膜の複素透磁率を最適化処
理で大まかに評価できることを示した ${ }^{4)}$. 本報告ではミア ンダ形のプローブを開発し，これを磁性薄膜に近接させる ことで高周波インピーダンス計測及び最適化処理により非 破壊に透磁率を評価した。これまでミアンダ形プローブに よる磁性薄膜の透磁率計測は報告されておらず，本プロー ブを用いることで，大きな試料サイズにも対応可能な透磁 率評価が可能になると考えられる．また本論文で開発した ミアンダ形プローブをウエハ上で走査することにより透磁 率の分布等を評価可能と考えられる.

\section{2. 透磁率計測方法}

\section{1 プローブの構造}

Fig. 1 はプローブの構成及び評価する磁性薄膜を模式的 に示した図である.プローブは 2 本のセミリジッドケーブ とミアンダ構造のマイクロストリップ線路で構成されてい る. マイクロストリップ線路は厚さ $0.5 \mathrm{~mm}$, 銅箔 $18 \mu \mathrm{m}$ のテフロン基板（CGK-500 XP0002，比誘電率 = 5）を使 用した。プリント基板加工機（ミッツ製 FP-21 型）により 幅 $0.8 \mathrm{~mm}$, 線間隔 $0.8 \mathrm{~mm}$, 長さ $5.0 \mathrm{~mm}, 3$ ターンのミ アンダ形状とし，特性インピーダンスはほぼ $50 \Omega$ とした. 本論文ではなるべく磁性薄膜の磁気信号を高い $\mathrm{SN}$ 比で計 測するために, 直線線路を折り曲げてプローブを構成した. 
隣接導体間の電気的な結合はある程度あるものの，補正等 はしていない。ミアンダ線路に流れる高周波電流は導体の 幅方向に高周波磁界を励磁するため, Fig. 1 の場合高周波 インピーダンスは，困難軸方向の透磁率に対応する．プロ

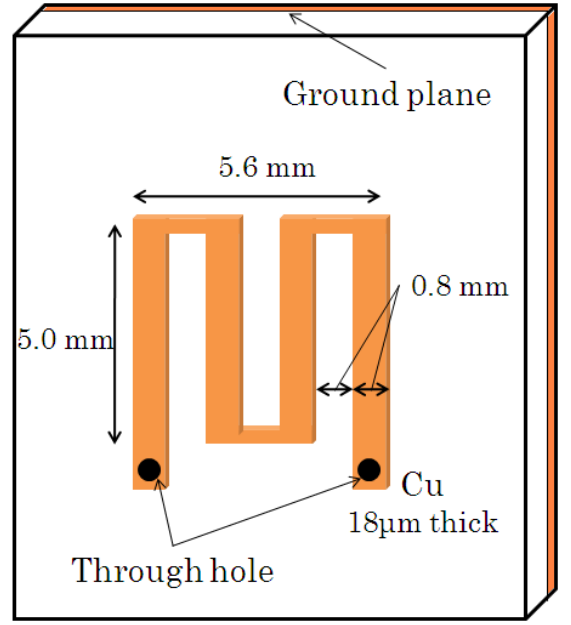

(a) Microstrip meander type probe

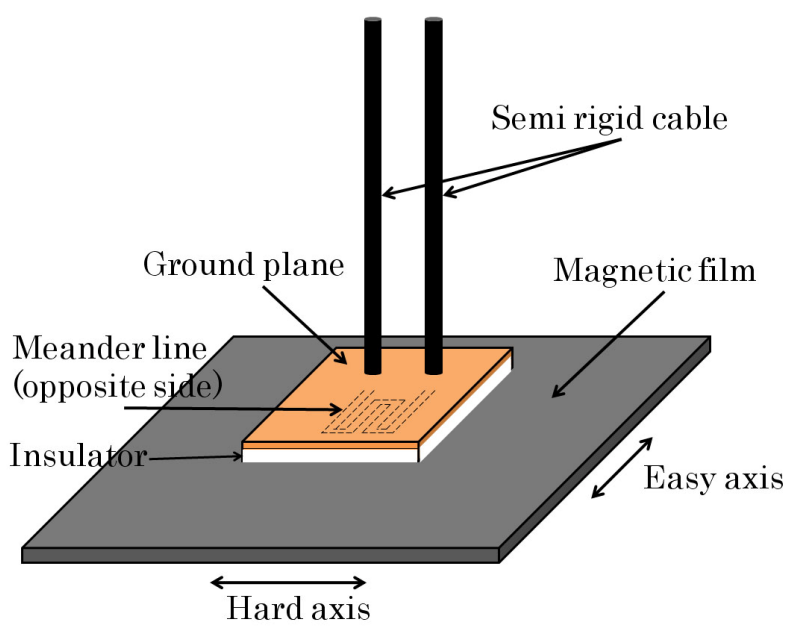

(b) Contacts between probe and magnetic film

Fig. 1 Schematic of probe.

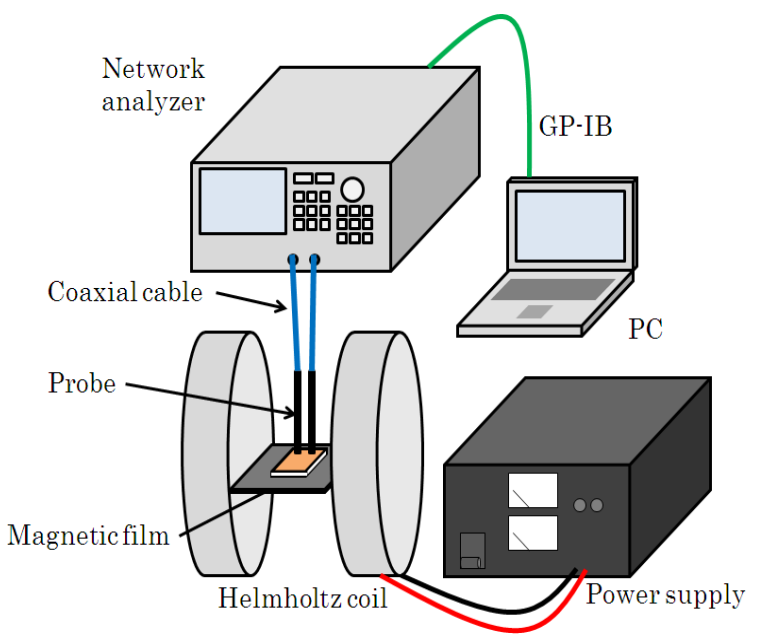

Fig. 2 Structure of measurement system.
ーブと磁性薄膜の間に絶縁体（ポリビニルフィルム，厚さ $10 \mu \mathrm{m} ）$ を挟み, 磁性薄膜にミアンダ線路を押し付けるこ とで磁性薄膜の高周波インピーダンスを計測する.

\section{2 透磁率の評価方法}

Fig. 2 は本計測システムの構成を示した図である. パソ コン, ネットワークアナライザ (ADVANTEST R3767CG)， プローブ，ヘルムホルツコイル，直流電源から構成されて おり，プローブは同軸ケーブルを介してネットワークアナ ライザに接続する。これらの装置から磁性薄膜の透過係数 $\left(S_{21}\right)$ を測定し，GP-IB でパソコンにデータを取り込み, 最適化処理により複素透磁率を求める. 本測定では磁性膜 を飽和させたバックグランド測定と主測定（直流磁界を 0 にした状態）の差分計測を行い，その差分が磁性膜の寄与 分であり，グランドプレーンを流れる電流の変化は十分小 さいと考えて透磁率を最適化した。

Fig. 3 に本計測システムの等価回路, Fig. 4 に計測のフロ 一チャートを示す. 本システムの計測手順は Fig. 2 のよう に結線し，プローブと磁性薄膜の間にポリビニルフィルム

（厚さ $10 \mu \mathrm{m}$ ）を挟んで近接させる. そして，ヘルムホル ツコイルの中に入れ約 $800 \mathrm{Oe}$ の直流磁界を加えて磁性薄 膜を飽和させ，ネットワークアナライザでキャリブレーシ ヨンする。これにより，プローブおよびケーブルの電気長， 磁性薄膜の直流的なインピーダンス，非磁性信号等を除去 する，その後，直流磁界を解除して磁性薄膜の寄与分の透 過係数（ $S_{21} ）$ を測定し，(1)式により磁性薄膜に近接するミ アンダ線路のインピーダンスを求める. Fig. 5 はマイクロ ストリップ導体および磁性薄膜の磁界および電流の様子を 模式的に示したものである。導電電流はマイクロストリッ プ導体に流れ，磁性薄膜内部では表皮効果により膜表面に 渦電流および電磁界が局在化すると考えられる. Fig. 4 の 最適化処理ではミアンダ線路に近接する磁性薄膜におい て，Fig. 5 の width の範囲で電流が表皮効果により膜厚方 向へほぼ 1 次元的に偏ることを仮定し，(2)〜(4)式を用いて Fig. 6 の Newton-Raphson 法により複素透磁率を最適化す る.

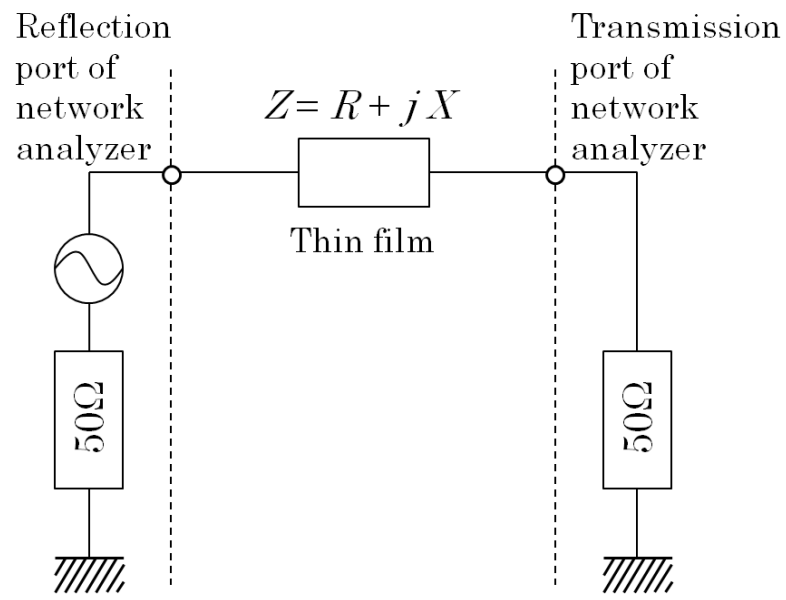

Fig. 3 Equivalent circuit. 


$$
\begin{gathered}
Z=50\left(1-S_{21}\right) \\
Z=\frac{k_{s} \rho l}{2 w} \operatorname{coth}\left(\frac{k_{s} t}{2}\right) \\
k_{s}=\frac{(1+j)}{\sqrt{\frac{\rho}{\pi f \mu_{r} \mu_{0}}}} \\
\mu_{r}=\mu_{r}^{\prime}-j \mu_{r}^{\prime \prime}
\end{gathered}
$$

ただし, $\rho$ は抵抗率, $I$ は試料長さ, $w$ は試料幅, $t$ は膜厚, $f$ は周波数, $\mu_{r}$ は複素比透磁率, $\mu_{0}$ は真空の透磁率である. ただし，本手法の適用は磁性薄膜内部の電流が表皮効果に 基づいて膜厚方向へ 1 次元的に偏る場合に適用可能であり, 2 次元的な電流の偏りが支配的になった場合には, 適用は困 難になると考えられる。

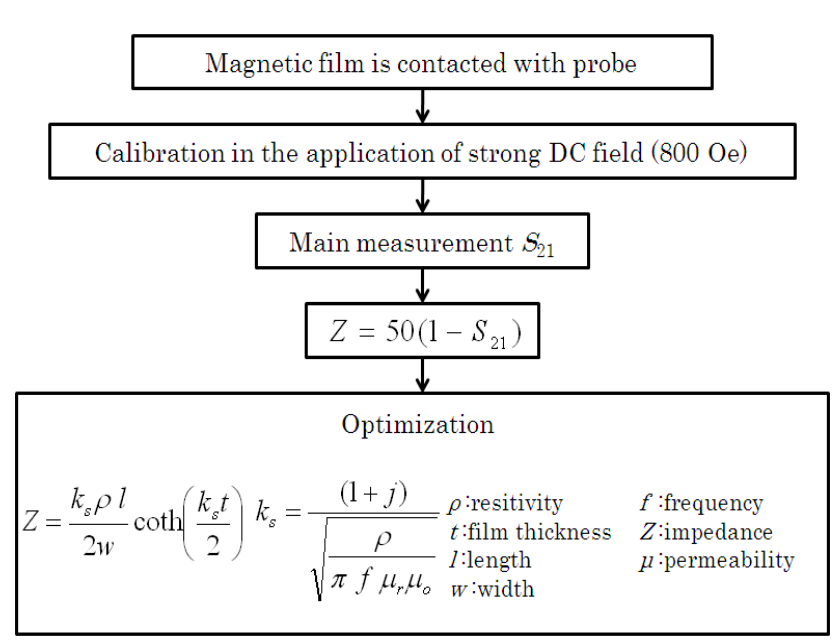

Fig. 4 Flow chart of measurement.

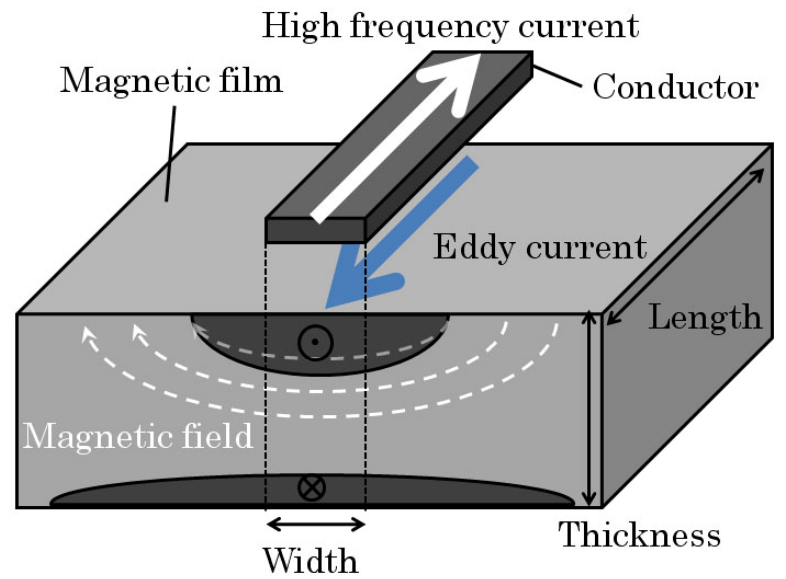

Fig. 5 Structure of thin film and skin effect.

\section{3. 評価結果}

\section{1 インピーダンスの測定結果}

Fig. 7 は評価に用いたアモルファス CoNbZr 薄膜（25 $\times 25 \mathrm{~mm}$, 厚み 0.1- $\mu \mathrm{m})$ の $\mathrm{M}-\mathrm{H}$ ループの測定結果であ る.この磁性薄膜は RF スパッタ法でガラス基板に $0.1 \mu \mathrm{m}$ 成膜し, その後熱処理により異方性を付与した. Fig. 7 よ り, 評価した磁性薄膜の異方性磁界 $H_{\mathrm{k}}$ は $40 \mathrm{Oe}$ 程度であ った.

Fig. 8 は本計測方法による高周波インピーダンスの測定 結果である. 低周波ではインピーダンスは 0 に近い值を示 しており, 周波数の増加に伴って表皮効果によりインピー ダンスが増加していることが分かる. 強磁性共鳴周波数の 前後ではリアクタンスが減少し, 抵抗分が極大值となって いる.

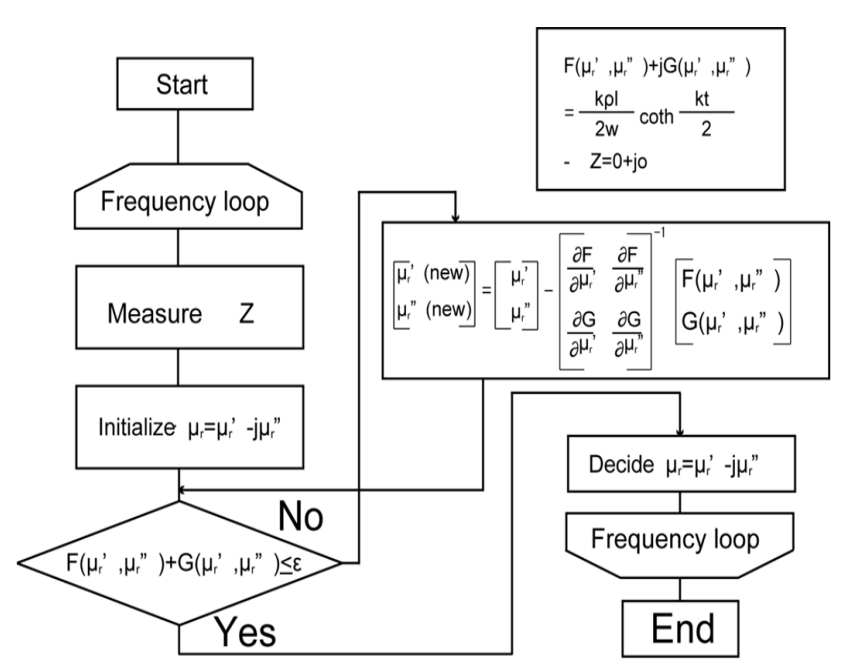

Fig. 6 Flow chart of Newton-Raphson method.

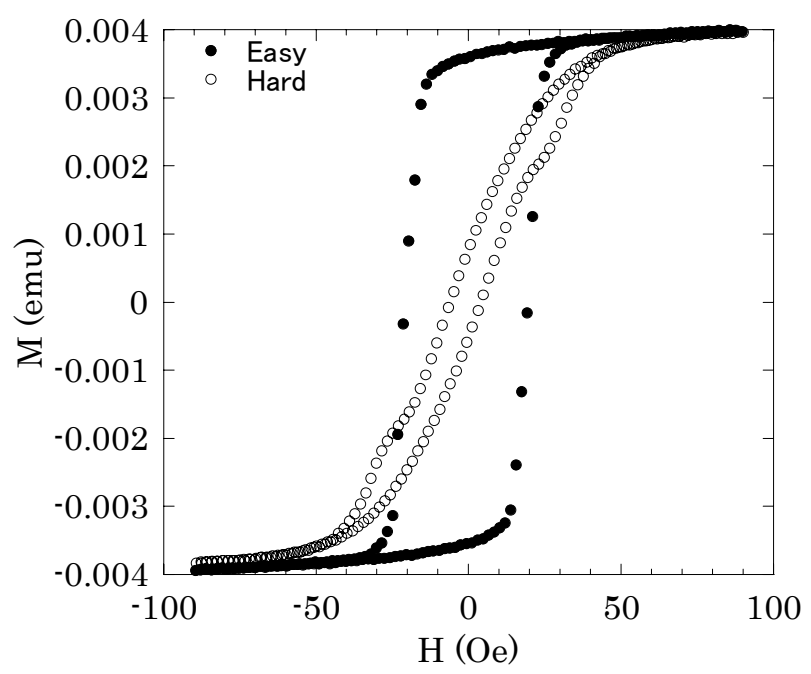

Fig. 7 Measured M-H loop of CoNbZr film $\left(25 \times 25 \mathrm{~mm}, 0.1^{-} \mu \mathrm{m}\right.$ thick $)$. 


\section{2 透磁率の計測結果}

Fig. 9 は Fig. 8 のインピーダンス測定結果から Fig. 4 の 最適化処理により求めた透磁率の計測結果である.

○及び ○が計測值であり, 実線及び破線は Fig. 7 の M-H ループか ら得られた異方性磁界（ $H_{\mathrm{k}}=40 \mathrm{Oe} ）$ に基づき LLG 方程式 と渦電流損を考慮した理論值 5)である。評価結果は大まか に理論值と対応しており, $1.8 \mathrm{GHz}$ 付近で強磁性共鳴が確 認された。誤差の主な原因は，作成した磁性薄膜の保磁力 $H_{\mathrm{c}}$ が大きいことやスルーホールによるはんだの若干の盛り 上がり等と考えられる。本手法は従来法と異なり，試料を 一様磁界中で励磁させる測定ではないため, 従来法に比較 して必ず何らかの誤差が生じると考えられる。本論文では

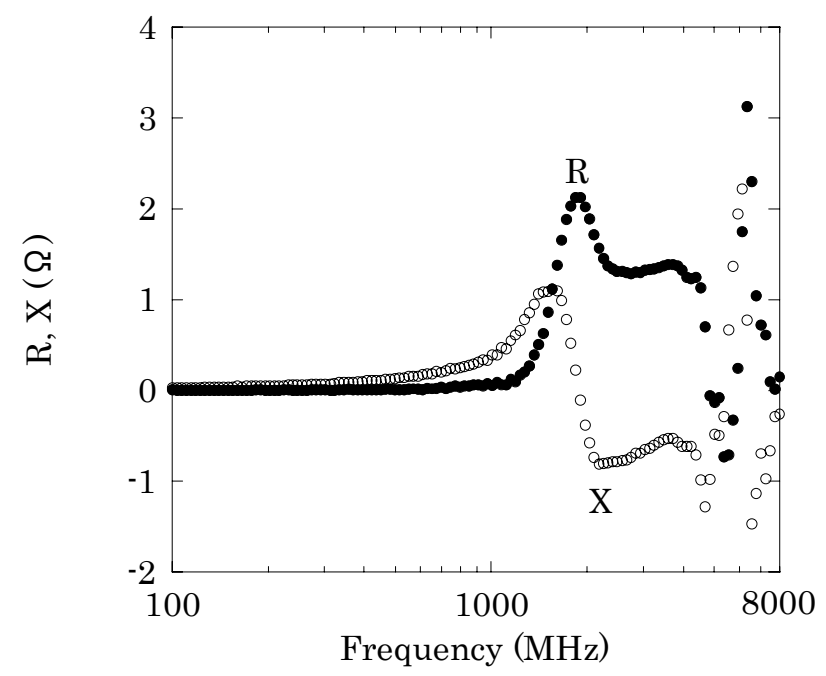

Fig. 8 Measured impedance of CoNbZr film $(25 \times 25 \mathrm{~mm}, 0.1-\mu \mathrm{m}$ thick $)$.

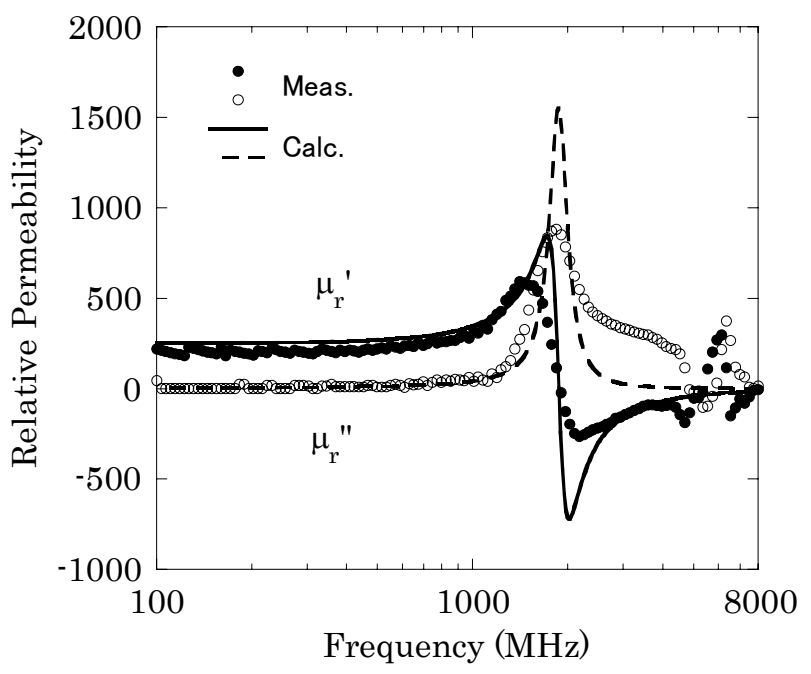

Fig. 9 Measured permeability of CoNbZr film $(25 \times 25 \mathrm{~mm}, 0.1-\mu \mathrm{m}$ thick $)$.
精密な評価ではなく, 強磁性共鳴周波数よりも低周波帯に おける透磁率の周波数依存性の傾向, および強磁性共鳴周 波数が LLG 方程式による理論值とほぼ対応することから 大まかに評価できたと考えられる。

\section{4. まとめ}

1. 磁性薄膜へミアンダ形プローブを近接させることで磁 性薄膜の高周波インピーダンスを計測し, 最適化処理によ り非破壊に透磁率を計測した。

2. $25 \times 25 \mathrm{~mm}$, 厚み 0.1- $\mu \mathrm{m}$ のアモルファス $\mathrm{CoNbZr}$ 薄 膜の透磁率を $100 \mathrm{MHz}-8 \mathrm{GHz}$ まで評価した. 共鳴周波数 以下の周波数依存性, および共鳴周波数が LLG 方程式によ る理論值とほぼ対応した。

3. 薄膜を特定サイズに切り出すことなく大まかな透磁率 が評価できた。

\section{5. 今後の展望}

本手法は，ミアンダ線路に流れる高周波電流によって磁 性薄膜に励磁される範囲の透磁率を計測している. そのた め, 大サイズのウエハや磁性薄膜の局所的な透磁率評価へ 応用することが考えられる. さらに, 磁性薄膜上を二次元 的に走查することで磁気特性の二次元分布を計測すること ができると考えられる.ただし, 磁性薄膜に流れる電流が 2 次元的に偏る場合や, 電流が迂回して流れるような条件に なると適用が困難になると考えられるため，その場合は， 解析的な最適化法は困難であり, 電磁界シミュレーション 等を実施して最適化する必要がある. また, CoNbZr 薄膜 以外の試料における透磁率の評価を検討している.

謝辞 本研究の一部は JST 地域ニーズ即応の成果である. 本研究に有益なご助言を頂きました宮城県産業技術総合セ ンターの熊谷実部長, インテリジェント・コスモス研究機 構の松本初男氏に感謝致します. 薄膜作製にご協力頂いた 宮城県産業技術総合センター中居倫夫氏に感謝致します. 治具製作にご協力いただいた東北学院大学工学部機械工場 スタッフの皆様に感謝致します.

\section{References}

1) P. A. Calcagno and D. A. Thompson: Rev. Sci. Instrum., Vol. 46, No. 7, 904 (1975).

2) M. Yamaguchi, S. Yabukami and K. I. Arai: IEEE Transaction on Magnetics. Vol. 32. No. 5. 4941 (1996).

3) W. B. WEIR: Proc IEEE, 62, 33 (1975).

4) S. Yabukami: Journal of Applied Physics. Vol. 105, 07E719 (2009).

5) Y. Shimada, J. Numazawa, Y. Yoneda and A. Hosono, J. Magn. Soc. Jpn. 15, 327 (1991).

2010 年 8 月 4 日受理, 2010 年 1 月 17 日採録 